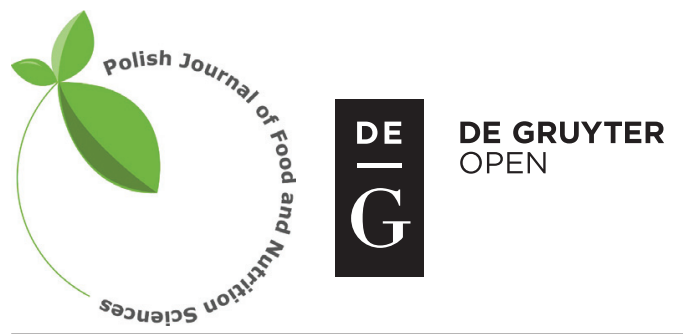

Pol. J. Food Nutr. Sci., 2017, Vol. 67, No. 2, pp. 137-144

DOI: $10.1515 /$ pjfns-2016-0014 http://journal.pan.olsztyn.pl

Original research article

Section: Food Quality and Functionality

\title{
Effect of Package Type on Selected Parameters of Nutritional Quality of Chill-Stored White Sauerkraut
}

\author{
Joanna Kapusta-Duch ${ }^{1 *}$, Barbara Kusznierewicz'2, Teresa Leszczyńska ${ }^{1}$, Barbara Borczak ${ }^{1}$ \\ ${ }^{1}$ Department of Human Nutrition, University of Agriculture in Kraków, Balicka 122, 30-149 Cracow, Poland \\ ${ }^{2}$ Department of Food Chemistry, Technology and Biotechnology, Gdańsk University of Technology, \\ 11/12 G. Narutowicza Str., 80-233 Gdańsk, Poland
}

Key words: antioxidant activity, fermentation, vegetables, total phenols, vitamin C, nutritional quality

Brassica vegetables, including white cabbage, both fresh and sour (Brassica oleracea L. var. capitata L.), contain a lot of valuable metabolites which are effective in chemoprevention of cancer as documented by numerous studies. This work investigates the effect of different packaging types; low density polyethylene (PE-LD) and metalized polyethylene terephthalate (PET met/PE) with polyethylene bags on selected quality parameters in chill-stored white sauerkraut. Sauerkraut was subjected to refrigerated storage for 4 months. Every month, stored sauerkraut was analyzed in terms of vitamin C, total phenolic compounds content and antioxidant activity. Statistical analysis demonstrated that the type of packaging had a significant influence on the antioxidant activity of chilled stored sauerkraut.

\section{INTRODUCTION}

Fermentation of vegetables based on lactic acid bacteria is one of the oldest forms of food preservation in the world. In this part of Europe, white cabbage, both fresh and sour, is one of the vegetables consumed in the largest quantities throughout the year; traditionally added to meat and highfat foods conducing cancer transformation. Due to high consumption and availability throughout the year, cabbage could potentially be a significant element in chemoprevention of cancer [Cabello-Hurtado et al., 2012; Kusznierewicz et al., 2008]. From the dietary point of view, Brassica vegetables, e.g. white cabbage, are a rich source of valuable vitamins with antioxidant properties, including vitamin $\mathrm{C}, \mathrm{PP}, \beta$-carotene, folic acid and $\alpha$-tocopherol and mineral compounds such as calcium, selenium, potassium, magnesium, and iron as well as antioxidants such as flavonoids, polyphenols and glucosinolates. Among non-nutritive compounds, it can be highlighted the presence of fiber, which is positively affecting intestinal peristalsis and goitrogens which have a negative effect on the human body. The latter, reducing the iodination of tyrosine, can lead to hypothyroidism [Girgin \& El Nehir, 2015; KapustaDuch et al., 2012; Peñas et al., 2015]. Sauerkraut, despite the losses of some compounds during fermentation, retains a high nutritional value and it is additionally enriched with precious compounds positively affecting the consumers' health. Furthermore, its flavour raises significantly and contributes to increasing consumption compared to the raw cabbage.

\footnotetext{
* Corresponding Author: Tel.: +48 1266248 16; Fax.: +48 1266248 12

E-mail: joannakapustaduch@interia.pl (J. Kapusta-Duch)
}

Lactic acid is a valuable constituent produced during fermentation process; the properly fermented raw material contains about $1600 \mathrm{mg} / 100 \mathrm{~g}$ fresh weight of this acid. From a chemical point of view, it is a 2-hydroxypropanoic or $\alpha$-hydroxypropionic acid, which demonstrates preservative properties due to its ability to inhibit the growth of coliforms and Clostridium bacteria. The acid protects products against enzymatic and chemical reactions contributing to changes in color, stability or appearance. In the human body, this acid acts as a protective layer of the skin and it is also involved in the defensive mechanisms occurring in the mucous membranes [Dinkova-Kostova \& Kostov, 2012; Gagné et al., 2015].

Nowadays, consumer demand for healthier and safer food products has prompted research on novel preservation techniques. The key elements responsible for the quality of food are the technologies used to process raw materials as well as the methods of food preservation. Temperatures used in chilling range from 0 to $10^{\circ} \mathrm{C}$ - the optimum temperature for the majority of the stored vegetables. Such values contribute to growth inhibition of pathogenic microorganisms, lower activity of enzymes, and limit the metabolic processes in vegetables [Costa et al., 2011; Gómez-Estaca et al., 2014].

Vitamin $\mathrm{C}$ and total polyphenols content in vegetables depends on several factors but mainly on the cultivar, stage of maturity at harvest, site and method of cultivation, agrotechnique, climatic conditions, storage, as well as technology of processing and preservation [Hounsome et al., 2009]. Various technological treatments such as cooking, pre-processing (washing, peeling, grinding) and storage may lead to significant declines in antioxidants, particularly in vita- 
min C. Vitamin C is highly labile, and long-term storage has a negative influence on its content. It has been reported that long-term storage, high temperatures or physical and chemical damage of the product enhance its losses [Grajek (ed.), 2007; Peñas et al., 2015]. Preliminary treatment of vegetables (peeling and cutting) leads also to enzymatic decomposition of total polyphenols or their decomposition due to the presence of oxygen. In addition, the long-term storage intensifies the processes of enzymatic or chemical oxidation of these substances to an extent depending on environmental factors such as, among others, temperature, $\mathrm{pH}$, water activity, time and the access to oxygen [Ninfali \& Bacchiocca, 2003]. Changes in the antioxidant activity in vegetables during their storage can be associated with changes in the level of antioxidants, for example, flavonoids, phenolic acids, amino acids, ascorbic acid, tocopherols and some pigments as well as with their mutual interactions [Chu et al., 2002].

In view of the above, a contemporary man is searching for effective methods of food storage to minimize losses occurring during this process. Hence, studies are conducted all over the world to find a method which will be beneficial from both nutritional and economic point of view and the use of which is inexpensive but efficient enough to maintain a natural composition of the stored product [Ambrosone \& Tang, 2009].

The role of packaging is quite wide and one of the most important functions of packaging is to protect the product against the external conditions as well as mechanical damages. Vegetables are a delicate raw material for storage; hence, the choice of suitable packaging has a strong influence on their quality. Packaging should be adjusted to physicochemical properties of the product such as, for example, its chemical composition or physical state. Selections of suitable packaging materials ensure a high quality of products with regard to their sensory and nutritional characteristics [Van Ooijen et al., 2016]. Muratore et al. [2015] have included the type and effectiveness of the packaging in a group of parameters characterizing the quality of food. The packaging is an integral part of the product. For the quality of stored food products, storage conditions are equally important. Soured products are usually stored in wooden, metallic or plastic barrels.

Barrier properties of the laminates used are the most important features of packaging. Plastic materials used for packaging should demonstrate good barrier properties for gas. They should also be hermetic against oxygen, water vapor, flavorings, carbon dioxide and nitrogen. Several factors can influence the barrier properties of a packaging material, like food contact and environmental conditions such as temperature and relative humidity. Permeates diffusion across a film is influenced by the film structure, film permeability to specific gases or vapour, thickness, area, temperature, difference in pressure, or concentration gradient across the film. The PE-LD properties include low permeability to water vapor and good permeability to gases, especially carbon dioxide [Hussein et al., 2015]. Aluminum foil (very thin sheeting with thickness from 0.00017 inch-4 $\mu$ to 0.0059 inch-150 $\mu$ ) is unique in providing essentially complete barrier to light, oxygen, or water vapor transmission. The coating reduces the permeability of the film to these factors. The properties of the film remain, such as higher toughness, the ability to be heat sealed, and a lower density at a lower cost than an aluminum foil. This gives metallized films some advantages over aluminum foil and aluminum foil laminates. The controlled permeation extends the shelf life [Dunn, 2015]. Individual packages, called also direct or internal, are characterized by limited capacity. The main task of such packaging type is to protect the product against quantitative as well as, to a slight extent, qualitative losses. Packaging may preserve the shelf life of minimally-processed products [Muratore et al., 2015].

In this work, the bags made from the metalized polyethylene terephthalate foil (PET met/PE) were used, which are not applied to pack vegetables in the industry. The aim of this paper was to examine and compare white sauerkraut, which was chill-stored for four months, in terms of changes in the vitamin $\mathrm{C}$, total polyphenols content as well as antioxidant activity. The experimental material was packed in two ways: in low density polyethylene (PE-LD) bags and in metalized polyethylene terephthalate (PET met/PE) bags. With a view to this goal, the research hypothesis tested was that the vitamin $\mathrm{C}$, total polyphenol contents and antioxidant activity in sauerkraut chill-stored for four months in two different packaging types differed statistically significantly.

To our best knowledge, this is the first study to analyze the effect of cold storage in different packaging types (especially innovative is one of presented packaging type - metalized foil made from PET met/PE) on the selected antioxidative properties of the chill-stored white sauerkraut. This study was also aimed at increasing the consumer's knowledge about the biological value of the sauerkraut, particularly with regard to the presence of such antioxidants as vitamin $\mathrm{C}$ and total polyphenols as well as antioxidant activity. In addition, the results should help to choose the container which will be the most suitable for the chilled storage of white sauerkraut.

\section{MATERIAL AND METHODS}

\section{Material}

The experimental material consisted of fresh white sauerkraut (the 'Stone head' variety), purchased in five different shops of Krakow. Acquisition of the research material was aimed at reflecting the situation of the average consumer, who buys the vegetable at the market places. Vegetables were analyzed before packaging and after 1, 2, 3 and 4 months of chilled storage in two types of packages: in low density polyethylene (PE-LD) bags with the zipper closure (foil density: $0.91-0.92 \mathrm{~g} / \mathrm{cm}^{3}$ ) and in bags of similar size made of laminate: metalized polyethylene terephthalate (PET met/ PE) (a polymer from the polyester group, obtained through a polycondensation reaction between dimethyl terephthalate (DMT) and ethylene glycol (GE), CAS number: 25038-59-9, density $1.370 \mathrm{~g} / \mathrm{cm}^{3}$ ) with polyethylene. The bags made of the laminate PET/met PE after packaging of the analyzed material were hermetically sealed using a welding machine. This packaging was innovative and had an interesting alternative for commonly used string bag, made of PE-LD.

The representative samples obtained were then stored at chilled conditions $\left(4-5^{\circ} \mathrm{C}\right)$ in a fridge for four subsequent months. There were a total of 8 bags, 4 from each package 
sort, containing an average of half a kilogram of the material analyzed. Packages were opened consecutively with the expiry of the research.

\section{Analytical methods}

Sauerkraut taken before packing and after the established periods of chilled storage from every container was collected and then homogenized using a homogenizer (CAT type X 120, CAT Scientific, Inc., USA) in order to obtain a mean representative sample.

Adequately prepared mean representative samples of vegetables were analyzed for vitamin $\mathrm{C}$ content - expressed as a sum of ascorbic and dehydroascorbic acid [PN-A-04019:1998]. Simultaneously, 70\% methanol extracts were prepared. The content of vitamin $\mathrm{C}$ was determined as the sum of ascorbic acid and dehydroascorbic acid using 2,6-dichlorophenoloindophenol according to the Polish Standard [PN-A-04019:1998]. An oxalic acid solution was used for extraction of ascorbic acid.

The content of total phenols in the extracts was determined spectrometrically (at a wavelength of $760 \mathrm{~nm}$ using a RayLeigh UV-1800 spectrophotometer (Beijing Rayleigh Analytical Instrument Corporation (BRAIC), China) according to the Folin-Ciocalteu procedure [Poli-Swain \& Hillis, 1959] and calculated as chlorogenic acid equivalents (CGA) (in milligrams) per $100 \mathrm{~g}$ of fresh or dry weight, based on a standard curve.

The method involved colorimetric determination of the content of the colored solution of $\mathrm{ABTS}^{*+}$ free radical $(2$, 2'-azinobis-(3-ethylbenzothiazoline-6-sulfonic acid) which was reduced by the antioxidants present in the tested product [Re et al., 1999]. The absorbance was measured at a wavelength of $734 \mathrm{~nm}$ using a RayLeigh UV-1800 spectrophotometer (Beijing Rayleigh Analytical Instrument Corporation (BRAIC), China). Values obtained for each sample were compared to the concentration-response curve of the standard Trolox solution and expressed as micromoles of Trolox equivalent to gram of fresh or dry weight (TEAC).

\section{Statistical analysis}

All analyses were carried out in three parallel replications $(n=3)$ and standard deviations (SD) were calculated for the obtained mean values. The one-way and two-way analysis of variance was employed to verify the significance of differences between the content of vitamin $\mathrm{C}$, polyphenols and differences in the $\mathrm{ABTS}^{\cdot+}$ free radical scavenging ability in the vegetables examined as affected by the process used (chilled storage) and the type of package used. The one-way analysis of variance was used to find the significance of differences between the mean values of the parameters investigated for the vegetable stored in two different types of package. The two-way analysis of variance was employed to establish the significance of differences between values of the parameters evaluated for the chill-stored vegetable depending on package type and chill-storage duration. The Statistica 9.1. PL software was applied for all calculations. The significance of differences between mean values was checked with the Duncan's multiple range test; differences were found significant at $\mathrm{p} \leq 0.05$.

\section{RESULTS AND DISCUSSION}

The results are discussed based on the dry matter (d.m.), thus eliminating the effect of water dilution on changes in the level of a constituent per a weight unit of the experimental material; as a result, only the effect of the technological process applied has been shown.

\section{Vitamin C}

Prior to packaging, the content of vitamin $\mathrm{C}$ in sauerkraut was $214.7 \mathrm{mg} / 100 \mathrm{~g}$ d.m. (Table 1). In the vegetables chill-stored for 4 months, vitamin $\mathrm{C}$ losses were as follows: in the products kept in the PE-LD bags: 46.6, 51.3, 36.4, and $51.7 \%$; while in those stored in the PET met/PE bags: $51.6,48.9,46.8$ and $53.6 \%$, compared to the non-stored sample (Figure 1).

Therefore the type of packaging used had no significant effect ( $p>0.05$ ) on vitamin $C$ content in the chill-stored white sauerkraut.

The content of vitamin $\mathrm{C}$ in sour cabbage depends on its content in the raw material, sauerkraut acidity and storage conditions. According to literature, vitamin $\mathrm{C}$ content in raw white cabbage fluctuates broadly between 18.0 and $54 \mathrm{mg} / 100 \mathrm{~g}$ fresh vegetable [Bahorun et al., 2004; Chu et al., 2002; Davey et al., 2000; Hrncirik et al., 2001; Jarczyk \& Płocharski, 2010; Pfendt et al., 2003; Puupponen-Pimia et al., 2003].Our results are similar to those reported by Peñas et al. [2015], who observed a vitamin $\mathrm{C}$ content of $20.1 \mathrm{mg} / 100 \mathrm{~g}$ in sauerkraut.

The large variation in the results could be attributed to different parameters of cultivation and post-harvest storage, or to different varieties studied. The content of vitamin $\mathrm{C}$ in the stored product depends, to a large extent, on vitamin level in the raw non-stored product.

This study revealed that vitamin $\mathrm{C}$ content in sauerkraut chill-stored in two different types of packages for 4 months decreased by $52.6 \%$ compared with the non-stored sauerkraut.

Czech \& Rusinek [2012] observed losses of this vitamin reaching $10.5 \%$ and $38.5 \%$ in raw white cabbage after storage at $0^{\circ} \mathrm{C}$ for 30 and 60 days, respectively. In the same study, the losses in vitamin $\mathrm{C}$ content determined in red cabbage were smaller: $8.2 \%$ after 30 days of storage and $34.9 \%$ after 60 days. Peñas et al. [2015] found that the content of vitamin $\mathrm{C}$ in natural fermented cabbage decreased significantly during conventional storage, and retentions of $77 \%, 50 \%$ and $35 \%$ were observed after 1, 2 and 3 months, respectively. Martinez-Villaluenga et al. [2009] reported that the fermentation process of cabbage led to significant reductions of this compound. Hounsome et al. [2009] found the loss of ascorbic acid in white cabbage of as much as $80 \%$ during 3-month storage at $1{ }^{\circ} \mathrm{C}$ compared to the fresh vegetable and a $50 \%$ decrease after 6-month chill-storage under identical conditions. There were no statistically significant changes with regard to dehydroascorbic acid. Many authors have received similar results [Grajek (ed.), 2007], which are consisted with those obtained in this work.

According to Nath et al. [2011], however, there were no considerable changes in vitamin $\mathrm{C}$ content in chill-stored broccoli which was packed in the polypropylene (PP) micro perforation bags, in comparison with the vegetable be- 


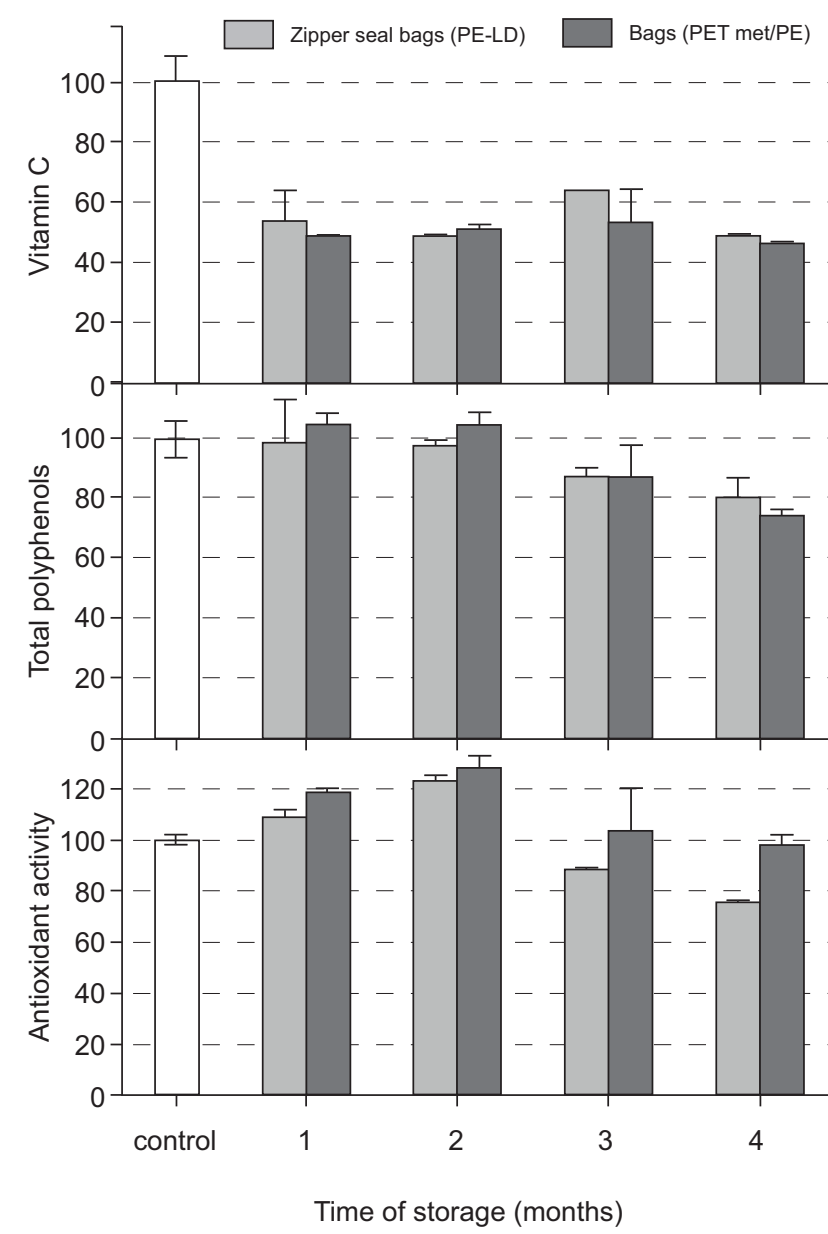

FIGURE 1. Changes in the content of vitamin C, total polyphenols and antioxidant activity in sauerkraut packed in two different types of bags (PE-LD and PET met/PE) during 4 months of chilled storage. The values are given as \% of control - assuming the results obtained for fresh sample as $100 \%$.

fore packaging. According to the findings of Kalt [2005], losses in vitamin $\mathrm{C}$ in broccoli after 6 days of storage in air, were within the range of $75-85 \%$. Apart from the activity of oxygen, vitamin $\mathrm{C}$ content in the plant material can also be affected by high temperatures, trace amounts of metals and enzymes as well as the method used to prepare the material for analyses [Martinez-Villaluenga et al., 2009]. Wieczorek \& Traczyk [1995] reported losses of 28 and 39\% in vitamin $\mathrm{C}$ in shredded white cabbage after 4 and $24 \mathrm{~h}$, respectively. The relative air humidity also considerably affects losses of vitamin C. Low humidity responsible for rapid wilting of vegetables, similarly as an increase in the concentration of ethylene, contribute to a significant decrease in vitamin C content [Lee \& Kader, 2000]. However, Czapski \& Szwejda [2006], who examined three species of fermented white cabbage, found that a 4-week period of chilled storage led to an increase in vitamin $\mathrm{C}$ content in sauerkraut compared to the initial value. Further 8 -week chilled storage contributed to a decrease of vitamin $\mathrm{C}$ content, on average, by $4 \%$, and after further 12 weeks by $23 \%$, when compared to the vegetable before storage.

In the available literature, there is no data concerning changes in this constituent in sour white cabbage which was chill-stored in various packages.
TABLE 1. Content of vitamin $\mathrm{C}$ in chill-stored white sauerkraut (mg/100 g d.m.).

\begin{tabular}{l|cc}
\hline Type of processing & \multicolumn{2}{|c}{ Vitamin C } \\
\hline Before storage & \multicolumn{2}{|c}{$214.7 \pm 19.3^{\mathrm{a}}$} \\
\hline \multirow{2}{*}{ Cool storage } & \multicolumn{2}{|c}{ Type of packaging } \\
\cline { 2 - 3 } & $\begin{array}{c}\text { Zipper seal bags } \\
\text { (PE-LD) }\end{array}$ & $\begin{array}{c}\text { Bags } \\
\text { (PET met/PE) }\end{array}$ \\
\hline 1 month & $114.7 \pm 22.9^{\mathrm{bc}}$ & $103.9 \pm 0.08^{\mathrm{bc}}$ \\
2 months & $104.5 \pm 1.66^{\mathrm{bc}}$ & $109.7 \pm 2.80^{\mathrm{bc}}$ \\
3 months & $136.6 \pm 0.22^{\mathrm{b}}$ & $114.2 \pm 24.5^{\mathrm{bc}}$ \\
4 months & $103.6 \pm 2.50^{\mathrm{bc}}$ & $99.7 \pm 0.66^{\mathrm{bc}}$ \\
\hline Mean value for packaging & $134.8 \pm 45.1^{\mathrm{A}}$ & $128.4 \pm 46.9^{\mathrm{A}}$ \\
\hline
\end{tabular}

Values are presented as mean value \pm standard deviation $(n=3)$. The values denoted with the same letters do not differ statistically significantly at $\mathrm{p} \leq 0.05$.

\section{Total polyphenols}

The content of total polyphenols was expressed as chlorogenic acid equivalent (Table 2). After 3- and 4-month chilled storage, losses observed in total polyphenols in sour white cabbage were significant $(\mathrm{p} \leq 0.05)$ and were respectively: 12.2 and $19.4 \%$, in the PE-LD bags; and 12.3 and $25.0 \%$ in the PET met/PE bags, compared to the values determined prior to packaging (Figure 1).

This study proved that the packaging type had no significant effect on the level of total polyphenols in the white sauerkraut stored under chilled conditions (Table 2).

The results obtained in the present study as well as literature data indicate a great diversity in the results presented by various authors. This proves considerable variability of the analyzed parameter. The total polyphenols content in the examined sour white cabbage reached $108.7 \mathrm{mg} / 100 \mathrm{~g}$ fresh product (expressed as chlorogenic acid). According to literature data, the content of total polyphenols in white cabbage ranges broadly from 15.3 to $58.0 \mathrm{mg} / 100 \mathrm{~g}$ fresh vegetable [Bahorun et al., 2004; Chu et al., 2002; Heo \& Lee, 2006; Proteggente et al., 2002]. The highest total polyphenol content in white cabbage $(203.0 \mathrm{mg} / 100 \mathrm{~g}$ fresh vegetable) has been determined by Wu et al. [2004], the results being calculated and expressed as gallic acid. In turn, Ciska et al. [2005] determined the total polyphenol content in white cabbage at $572.0 \mathrm{mg} / 100 \mathrm{~g}$ (expressed as gallic acid), which agrees with the findings of Heimler et al. [2006] - 531.0 mg/100 g vegetable d.m. (also expressed as gallic acid); although, according to Ismail et al. [2004] the content of total polyphenols reached $1107.0 \mathrm{mg} / 100 \mathrm{~g}$. Vinson et al. [1998], Podsędek et al. [2004], and Kaur \& Kapoor [2002], who calculated total polyphenols per catechin, found the following values: 20.6, 15.0 , and $92.5 \mathrm{mg} / 100 \mathrm{~g}$ fresh vegetable, respectively.

Literature data usually show the content of total polyphenols in Brassicas with reference to kaempferol, gallic acid and catechin. Vegetables are primarily a source of polyphenolic compounds from the group of phenolic acids, since the proportion of flavonoids to the total polyphenol content ranges from $4 \%$ in white cabbage and Italian cabbage to 39\% 
TABLE 2. Content of total polyphenols in chill-stored white sauerkraut (mg CGA/100 g d.m.).

\begin{tabular}{l|c|c}
\hline \multirow{2}{*}{ Type of processing } & \multicolumn{2}{|c}{ Total polyphenols } \\
\hline Before storage & \multicolumn{2}{|c}{$1120.6 \pm 68.9^{\mathrm{a}}$} \\
\hline \multirow{2}{*}{ Cool storage } & \multicolumn{2}{|c}{ Type of packaging } \\
\cline { 2 - 3 } & $\begin{array}{c}\text { Zipper seal bags } \\
\text { (PE-LD) }\end{array}$ & $\begin{array}{c}\text { Bags } \\
\text { (PET met/PE) }\end{array}$ \\
\hline 1 month & $1110.0 \pm 158.3^{\mathrm{a}}$ & $1180.0 \pm 40.2^{\mathrm{a}}$ \\
2 months & $1101.3 \pm 18.4^{\mathrm{a}}$ & $1181.5 \pm 39.0^{\mathrm{a}}$ \\
3 months & $983.6 \pm 33.5^{\mathrm{b}}$ & $982.5 \pm 119.4^{\mathrm{b}}$ \\
4 months & $903.2 \pm 74.9^{\mathrm{bc}}$ & $840.9 \pm 19.3^{\mathrm{c}}$ \\
\hline Mean value for packaging & $1043.7 \pm 116.6^{\mathrm{A}}$ & $1061.1 \pm 147.8^{\mathrm{A}}$ \\
\hline
\end{tabular}

Values are presented as mean value \pm standard deviation $(n=3)$. The values denoted with the same letters do not differ statistically significantly at $\mathrm{p} \leq 0.05$.

in red cabbage [Chun et al., 2004; Karadeniz et al., 2005]. According to literature data, the content of flavonoids other than derivatives of flavonols and flavones is low in vegetables. White cabbage contains over 20 compounds of quercetin and kaempferol, including quercetin and kaempferol 3-sophoroside-7-glucoside and kaempferol 3,7-diglucoside) as well as their forms acylated with hydroxycinnamic acids [Bahorun et al., 2004; Nielsen et al., 1998].

As proved by Grajek (ed.) [2007], the concentration of phenolic acids may increase or decrease during the growth of Brassica vegetables, whereas during storage it decreases rapidly. In the case of polyphenolic compounds, which are very diverse in terms of structure and properties, conditions of the extraction from raw materials are no less important than methods of analysis. Large discrepancies in the values of total polyphenols reported by the aforementioned authors may be due to different methods used to extract polyphenolic compounds from raw materials; they applied both 50 and $70 \%$ methanol, and 70 or $80 \%$ acetone as well as $70 \%$ acetone acidified with acetic acid. Another reason may be a different manner in which the results are calculated depending on the applied standard. As it was observed in this work, after chilled storage for 4 months, the content of total polyphenols in sauerkraut decreased significantly (32.7\%) compared with the non-stored sauerkraut. The factors affecting significantly the changes in the level of polyphenolic compounds include duration and temperature of cold storage as well as the degree of damage to vegetable tissue [Martinez-Valverde et al., 2002]. Bunea et al. [2008] found that losses of total polyphenols in the spinach chill-stored for 24 and $72 \mathrm{~h}$ were $7.6 \%$ and $11.6 \%$ respectively when compared to the fresh vegetable. Vina \& Chaves [2006] investigated the effect of chilled storage at $0^{\circ} \mathrm{C}$ and $4^{\circ} \mathrm{C}$ for $0,7,14,21$ and 28 days on the content of total phenolic compounds in portioned celery leaves packaged in polystyrene trays (PS) and sealed with PVC foil. The authors stated that at the end of the experiment the content of these constituents in the vegetable stored at $0^{\circ} \mathrm{C}$ remained unchanged, while in those stored at $4^{\circ} \mathrm{C}$ it increased slightly by $25 \%$. On the other hand, Amanatidou et al. [2000] dem-
TABLE 3. Antioxidant activity in chill-stored white sauerkraut ( $\mu \mathrm{m}$ Trolox/g d.m.).

\begin{tabular}{l|c|c}
\hline \multirow{2}{*}{ Type of processing } & \multicolumn{2}{|c}{ Antioxidant activity } \\
\hline Before storage & \multicolumn{2}{|c}{$192.0 \pm 3.56^{\mathrm{cd}}$} \\
\hline \multirow{2}{*}{ Cool storage } & \multicolumn{2}{|c}{ Type of packaging } \\
\cline { 2 - 3 } & $\begin{array}{c}\text { Zipper seal bags } \\
\text { (PE-LD) }\end{array}$ & $\begin{array}{c}\text { Bags } \\
(\text { PET met/PE) }\end{array}$ \\
\hline 1 month & $208.5 \pm 6.51^{\mathrm{c}}$ & $228.6 \pm 1.95^{\mathrm{b}}$ \\
2 months & $236.1 \pm 4.53^{\mathrm{ab}}$ & $246.6 \pm 7.73^{\mathrm{a}}$ \\
3 months & $169.7 \pm 1.15^{\mathrm{e}}$ & $199.8 \pm 31.7^{\mathrm{cd}}$ \\
4 months & $144.6 \pm 2.31^{\mathrm{f}}$ & $189.4 \pm 5.80^{\mathrm{d}}$ \\
\hline Mean value for packaging & $190.2 \pm 32.4^{\mathrm{B}}$ & $211.3 \pm 26.6^{\mathrm{A}}$ \\
\hline
\end{tabular}

Values are presented as mean value \pm standard deviation $(n=3)$. The values denoted with the same letters do not differ statistically significantly at $\mathrm{p} \leq 0.05$.

onstrated an 8-fold increase in total polyphenols in the sliced carrot stored at $8^{\circ} \mathrm{C}$ for 12 days compared to the fresh vegetable. Gil-Izuaredo et al. [2002] reported an increase in chlorogenic acid content in artichoke stored at temperatures ranging from 0 to $7^{\circ} \mathrm{C}$ for 14 days; the increase was greater in internal than external parts of the vegetable. Babic et al. [1993] observed both an increase and a decrease in chlorogenic acid content in minimally-processed carrot after maximum three days of storage at $4^{\circ} \mathrm{C}$. According to the aforementioned authors, an increase in the content of phenolic compounds was probably caused by the physiological response of vegetables to their infection and damage. In the eight lettuce varieties and three endive varieties stored in the dark at $1{ }^{\circ} \mathrm{C}$ and humidity of $98 \%$, the total content of flavonoid glycosides decreased substantially by $7-46 \%$ after 7 days of storage, except for one lettuce variety characterized by a relatively less content of these compounds [DuPont et al., 2000].

Storage in different packages had no significant effect ( $p>0.05$ ) on the content of total polyphenols in sauerkraut. However, there is no literature data on the impact of these types of packages on selected health-promoting properties of foods stored in them.

\section{Antioxidant activity}

Antioxidant activity in white sauerkraut has been calculated as as micromoles of Trolox equivalent per gram of dry weight (Table 3$)$. The following significant changes $(\mathrm{p} \leq 0.05)$ of the antioxidant activity were observed in the sauerkraut after 2-, 3- and 4-month chilled storage in the PE-LD bags: $+23.0 \%$ (an increase in antioxidant potential) and -11.6 and $-24.7 \%$ (a decrease), in comparison with the non-stored vegetable (Figure 1).

In the vegetables kept in the PET met/PE bags, a significant increase in this parameter was noted only after 1- and 2-month chilled storage, which accounted for 19.1 and $28.4 \%$ respectively, compared to the vegetable prior to packaging.

It was proved that the type of packaging had a significant $(p \leq 0.05)$ effect on the antioxidant potential of chill-stored 
sour cabbage. The sour cabbage from the PET met/PE bags had a higher antioxidant activity than the sour cabbage from the PE-LD zipped bags (Table 3 ).

In the present study, the antioxidant activity assayed in sauerkraut before packaging agrees with the findings of Ciska et al. [2005], who determined the antioxidant activity in cabbage sauerkraut at $20.0 \mu \mathrm{mol}$ Trolox eq./g fresh vegetable. Other authors reported lower values of the antioxidant activity in white cabbage before fermentation, i.e. between 1.3 and $13.6 \mu \mathrm{mol}$ Trolox eq./g fresh vegetable [Cao et al., 1996; Cieślik et al., 2005; Peñas et al., 2015; Podsędek et al., 2006; Szajdek \& Borowska, 2004; Ou et al., 2002; Wu et al., 2004]. After 4 months of chilled storage, the antioxidant activity decreased in white cabbage sauerkraut stored in both types of packages; its losses compared to sauerkraut before packaging were $36 \%$ in the sauerkraut stored in the PE-LD bags and $12.9 \%$ in the sauerkraut stored in the PET met/PE bags. This confirms the findings of Murcia et al. [2009], who found decreases in the antioxidant activity of various vegetables, i.e. by $3 \%$ in broccoli, by $4 \%$ in cauliflower and by $34.1 \%$ in zucchini after 7 days of storage at $4^{\circ} \mathrm{C}$, compared to fresh vegetables. On the other hand, no significant changes of the antioxidant activity were observed by Peñas et al. [2015], during the storage of naturally obtained sauerkraut both at conventional and $\mathrm{N}_{2}$-enriched atmospheres. Kusznierewicz et al. [2010] observed that the process of fermentation increased 3-4-fold the antioxidant activity of cabbage. Sun et al. [2009], also reported an increased antioxidant activity in spontaneously fermented Chinese cabbage. According to Vina \& Chaves [2006], taking into account different storage temperatures $\left(0,4\right.$, and $\left.10^{\circ} \mathrm{C}\right)$, the antioxidant capacity of celery leaves did not differ significantly after 28 days. The authors observed that the antioxidant potential of cut celery initially decreased after 7 days of storage and then increased after 2 weeks, regardless of storage temperature. It has been proved that for the examined temperatures there was a linear correlation between the antioxidant capacity and changes in vitamin C content during storage of celery. As reported by Gil et al. [1999], the antioxidant activity of spinach was decreasing throughout a 7-day period of storage at $10^{\circ} \mathrm{C}$ both in the air and in the modified atmosphere $\left(\mathrm{CO}_{2}\right.$ and $\left.\mathrm{O}_{2}\right)$.

In this study, however, the antioxidant activity of the sauerkraut stored in PET met/PE bags was significantly higher than in that kept in the PE-LD bags. There is no literature data on the impact of these types of packages on the selected health-promoting properties of the foods stored in them. Nath et al. [2011] found no significant changes in the antioxidant activity of broccoli after $144 \mathrm{~h}$ of its chilled storage in the micro-perforated bags from the polypropylene (PP) film; whereas, after this time, a $49.5 \%$ decline in the antioxidant activity was observed in the broccoli packed in perforated plastic bags.

The differences in the results obtained in the course of this work, compared to literature data may arise from, as in the case of polyphenols, different experimental conditions (the storage temperature and times, other packaging material or their) as well as from the analyzed vegetable species, and various methods applied for antioxidant activity determination (FRAP, ABTS, DPPH, ORAC methods).

\section{CONCLUSIONS}

Refrigerated storage of sauerkraut for 4 months caused a statistically significant reduction in the constituents examined: on average by $52.6 \%$ in vitamin C; $32.7 \%$ in total polyphenols and $24.4 \%$ in antioxidant activity, regardless of a type of the packaging used. It has also been proved that the type of the packaging used did not affect significantly the content of vitamin C and total polyphenols. On the other hand, the antioxidant activity of the sauerkraut stored in PET met/ PE bags was significantly higher than in that kept in the PELD bags. Finally, the results of this work enabled the choice of the container, which will be the most suitable for the storage of white sauerkraut, which is bag made of laminate: metalized polyethylene terephthalate (PET met/PE) with polyethylene. However, further studies are still necessary to evaluate other aspects (different storage time, other packaging materials, additional technologies, etc.) that could improve the quality features of the chilled stored white sauerkraut.

\section{RESEARCH FUNDING}

The work was funded as statutory research by the Department of Human Nutrition, Faculty of Food Technology, University of Agriculture in Kraków.

\section{CONFLICT OF INTEREST}

Authors declare no conflict of interest.

\section{REFERENCES}

1. Amanatidou A., Slump R.A., Gorris L.G.M., Smid E.J., High oxygen and high carbon dioxide modified atmospheres for shelflife extension of minimally processed carrots. J. Food Sci., 2000, 65, 61-66.

2. Ambrosone C.B., Tang L., Cruciferous vegetables intake and cancer prevention: role of nutrigenetics. Cancer Prev. Res., 2009, 2, 298-300.

3. Babic I., Amiot M.J., Nguyen-The C., Aubert S., Changes in phenolic content in fresh ready-to-use shredded carrots during storage. J. Food Sci., 1993, 58, 351-356.

4. Bahorun T., Luximon-Ramma A., Crozier A., Aruroma O.I., Total phenol, flavonoid, proanthocyanidin and vitamin C levels and antioxiadant activities of Mauritian vegetables. J. Food Sci. Agric., 2004, 84, 1553-1561.

5. Bunea A., Andjelkovic M., Socaciu C., Bobis O., Neacsu M., Verhe R., Van Camp J., Total and individual carotenoids and phenolic acids content in fresh, refrigerated and processed spinach (Spinacia oleracea L.). Food Chem., 2008, 108, 649-656.

6. Cabello-Hurtado F., Gicquel M., Esnault M.-A., Evaluation of the antioxidant potential of cauliflower (Brassica oleracea) from a glucosinolate content perspective. Food Chem., 2012, 132, 1003-1009.

7. Cao C., Sofic E., Prior R., Antioxidant capacity of tea and common vegetables. J. Agric. Food Chem., 1996, 44, 3426-3431.

8. Chu Y.-F., Sun J., Wu X., Liu R.H., Antioxidant and antiproliferative activities of common vegetables. J. Agric. Food Chem., 2002, 50, 6910-6916. 
9. Chun OK, Smith N, Sakagawa A, Lee C.H.Y., Antioxidant properties of raw and processed cabbages. Int. J. Food Sci. Nutr., 2004, 55, 191-199.

10. Cieślik E., Pisulewski P.M., Filipiak-Florkiewicz A., Leszczyńska T., Sikora E., Antioxidant potential of selected brassica vegetables. Żyw. Człow. Metab., 2005, 32, 1093-1097 (in Polish).

11. Ciska E., Karamać M., Kosińska A., Antioxidant activity of extracts of white cabbage and sauerkraut. Pol. J. Food Nutr. Sc., 2005, 14, 367-373.

12. Costa C., Lucera A., Conte A., Mastromatteo M., Speranza B., Antonacci A., Del Nobile M.A., Effects of passive and active modified atmosphere packaging conditions on ready-to-eat table grape. J. Food Eng., 2011, 102, 115-121.

13. Czapski J., Szwejda J., Antioxidant responses in fermented cabbage and juice during storage. Veg. Crop Res. Bull., 2006, 64, 39-50.

14. Czech A., Rusinek E., The content of the antioxidant compounds in selected cruciferous vegetables. Bromat. Chem. Toksykol., 2012, 45, 59-65 (in Polish).

15. Davey M.W., Van Montagu M., Inze D., Sanmartin M., Kanellis A., Smirnoff N., Benzie I.J.J., Strain J.J., Favell D., Fletcher J., Plant L-ascorbic acid: chemistry, function, metabolism, bioavailability and effects of processing. J. Sci. Food Agric., 2000, 80, 825-860.

16. Dinkova-Kostova A.T., Kostov R.V., Glucosinolates and isothiocyanates in health and disease. Trends Mol. Med., 2012, 18, 337-347.

17. Dunn T., Materials, machinery and techniques. Flex. Pack., 2015, $161-165$.

18. DuPont M.S., Mondin Z., Willamson G., Price K.R., Effect of variety, processing, and storage on the flavonoid glycoside content and composition of lettuce and endive. J. Agric. Food Chem., 2000, 48, 3957-3964.

19. Gagné M.-J., Barrette J., Savard T., Brassard J., Evaluation of survival of murine norovirus-1 during sauerkraut fermentation and storage under standard and low-sodium conditions. Food Microbiol., 2015, 52, 119-123.

20. Gil M.I., Ferreres F., Tomas-Barberan F.A., Effect of postharvest storage and processing on the antioxidant constituents (flavonoids and vitamin C) of fresh-cut spinach. J. Agric. Food Chem., 1999, 47, 2213-2217.

21. Gil-Izquierdo A., Gil M.I., Ferreres F., Effect of processing techniques at industrial scale on orange juice antioxidant and beneficial health compounds. J. Agric. Food Chem., 2002, 50, 5107-5114.

22. Girgin N., El Nehir S., Effects of cooking on in vitro sinigrin bioaccessibility, total phenols, antioxidant and antimutagenic activity of cauliflower (Brassica oleraceae L. var. Botrytis). J. Food Comp. Anal., 2015, 37, 119-127.

23. Gómez-Estaca J., López-de-Dicastillo C., Hernández-Muñoz P., Catalá R., Gavara R., Advances in antioxidant active food packaging. Trends Food Sci. Technol., 2014, 35, 42-51.

24. Grajek W. (ed.). Antioxidants in food. Health aspects, technological, and molecular analysis. 2007, Publishing house WNT, Warszawa (in Polish).

25. Heimler D., Vignolini P., Dini M.G., Vincieri F.F., Romani A., Antiradical activity and polyphenol composition of local Brassicaceae edible varieties. Food Chem., 2006, 99, 464-469.

26. Heo H.J., Lee C.H.Y., Phenolic phytochemicals in cabbage inhibit amyloid b protein-induced neurotoxicity. LWT - Food Sci. Technol., 2006, 39, 330-336.
27. Hounsome N., Hounsome B., Tomos D., Edwards-Jones G., Changes in antioxidant compounds in white cabbage during winter storage. Postharv. Biol. Technol., 2009, 52, 173-179.

28. Hrncirik K., Valusek J., Velisek J., Investigation of ascorbigen as a breakdown product of glucobrassicin autolysis in Brassica vegetables. Eur. Food Res. Technol., 2001, 212, 576-581.

29. Hussein Z., Caleb O.J., Opara U.L., Perforation-mediated modified atmosphere packaging of fresh and minimally processed produce-A review. Food Pack. Shelf Life, 2015, 6, 7-20.

30. Ismail A., Marjan Z.M., Foong Ch.W., Total antioxidant activity and phenolic content in selected vegetables. Food Chem., 2004, 87, 581-586.

31. Jarczyk A., Płocharski W., Technology of fruit and vegetable products. 2010, wyd. WSE-H (in Polish).

32. Kalt W., Effects of production and processing factors on major fruit and vegetable antioxidants. J. Food Sci., 2005, 70, R11-R19.

33. Kapusta-Duch J., Kopeć A., Piątkowska E., Borczak B., Leszczyńska T., The Beneficial effects of Brassica vegetables on human health. Rocz. Panstw. Zakl. Hig., 2012, 63, 389-395.

34. Karadeniz F., Burdurlu H.S., Koca N., Soyer Y., Antioxidant activity of selected fruits and vegetables grown in Turkey. Turk. J. Agric. For., 2005, 29, 297-303.

35. Kaur Ch., Kapoor H.C., Antioxidant activity and total phenolic content of some Asian vegetables. Int. J. Food Sci. Tech., 2002, 37, 153-161.

36. Kusznierewicz B., Lewandowska J., Kruszyna A., Piasek A., Śmiechowska A., Namieśnik J., The antioxidative properties of white cabbage (Brassica oleracea var. Capitata F. alba) fresh and submitted to culinary processing. J. Food Biochem., 2010, SI, 34, 262-285.

37. Kusznierewicz B., Śmiechowska A., Bartoszek A., Namieśnik J., The effect of heating and fermenting on antioxidant properties of white cabbage. Food Chem., 2008, 108, 853-861.

38. Lee S.K., Kader A.A., Preharvest and postharvest factors influencing vitamin $\mathrm{C}$ content of horicultural crops. Postharv. Biol. Technol., 2000, 20, 207-220.

39. Martinez-Valverde I., Periago M.J., Provan G., Chesson E., Phenolic compounds, lycopene and antioxidant activity in commercial varieties of tomato (Lycopersicon esculentum). J. Sci. Food Agric., 2002, 82, 323-330.

40. Martinez-Villaluenga C., Peñas E., Frias J., Ciska E., Honke J., Piskula M.K., Kozlowska H., Vidal-Valverde C., Influence of fermentation conditions on glucosinolates, ascorbigen, and ascorbic acid content in white cabbage (Brassica oleracea var. capitata cv. Taler) cultivated in different seasons. J. Food Sci., 2009, 74, C62-C67.

41. Muratore G., Restuccia C., Licciardello F., Lombardo S., Pandino G., Mauromicale G., Effect of packaging film and antibrowning solution on quality maintenance of minimally processed globe artichoke heads. Innov. Food Sci. Emerg. Technol., 2015, 31, 97-104.

42. Murcia M.A., Jimenez A.M., Martinez-Tome M., Vegetables antioxidant losses during industrial processing and refrigerated storage. Food Res. Int., 2009, 42, 1046-1052.

43. Nath A., Bagchi B., Misra L.K., Deka B.C., Changes in postharvest phytochemical qualities of broccoli florets during ambient and refrigerated storage. Food Chem., 2011, 127, 1510-1514.

44. Nielsen J.K., Norbaek R., Olsen C.E., Kaempferol tetraglucosides from cabbage leaves. Phytochemistry, 1998, 49, 2171-2176. 
45. Ninfali P., Bacchiocca M., Polyphenols and antioxidant capacity of vegetables under fresh and frozen conditions. J. Agric. Food Chem., 2003, 51, 2222-2226.

46. Ou B., Huang D., Hampsch-Woodill M., Flanagan J.A., Deemer E.K., Analysis of antioxidant activities of common vegetables employing oxygen radical absorbance capacity (ORAC) and ferric reducing antioxidant power (FRAP) assays: A comparative study. J. Agric. Food Chem., 2002, 50, 3122-3128.

47. Peñas E., Martínez-Villaluenga C., Pihlava J.-M., Frias J., Evaluation of refrigerated storage in nitrogen-enriched atmospheres on the microbial quality, content of bioactive compounds and antioxidant activity of sauerkrauts. LWT - Food Sci. Technol., 2015, 61, 463-470.

48. Pfendt L.B., Vukasinovic V.L., Blagojevic N.Z., Radojevic M.P., Second order derivative spectrophotometric method for determiantion of vitamin $\mathrm{C}$ content in fruits, vegetables and fruit juices. Eur. Food Res. Technol. 2003, 217, 269-272.

49. Podsędek A, Sosnowska D, Łoś J., Antiradical assessment of the effectiveness of polyphenols of selected vegetables. V Conference "The flavonoids and their application". Rzeszów, 2004, 66-276 (in Polish).

50. Podsędek A., Sosnowska D., Redzynia M., Andres B., Antioxidant capacity and content of Brassica oleracea dietary antioxidants. Int. J. Food Sci. Technol., 2006, 41, Suppl. 1, 49-58.

51. Polish Standard. 1998. PN-A-04019:1998. Polish Committee for Standardization. Food products - Determination of vitamin C (in Polish).

52. Poli-Swain T., Hillis W.E., The phenolic constituents of Prunus Domesticus (L.). The quantity of analysis of phenolic constituents. J. Sci. Food Agric., 1959, 10, 63-68.

53. Proteggente A.R., Pannala A.S., Paganga G., Van Buren L., Wagner E., Wiseman S., Van de Put F., Dacombe C., Rice-Evans C.E., The antioxidant activity of regulatory consumed fruit and vegetables reflects their phenolic and vitamin C. Free Radical Res., 2002, 36, 217-233.
54. Puupponen-Pimia R., Hakkinen S.T., Aarni M., Suortti T., Lampi A.M., Eurola M., Blanching and long-term freezing effect various bioactive compounds of vegetables in different ways. J. Sci. Food Agric., 2003, 83, 1389-1402.

55. Re R., Pellegrini N., Proteggente A., Pannala A., Yang M., RiceEvans C., Antioxidant activity applying an improved ABTS radical cation decolorization assay. Free Radical Biol. Med., 1999, 26, 1231-1237.

56. Sun Y.-P., Chou C.-C., Yu R.-C., Antioxidant activity of lacticfermented Chinese cabbage. Food Chem., 2009, 115, 912-917.

57. Szajdek A., Borowska J., The antioxidant properties of plant foods. Żywność, Nauka, Technologia, Jakość, 2004, 41, 5-23 (in Polish).

58. Van Ooijen I., Fransen M.L., Verlegh P.W.J., Smit E.G., Atypical food packaging affects the persuasive impact of product claims. Food Qual. Prefer., 2016, 48, 33-40.

59. Vina S.Z., Chaves A.R., Antioxidant responses in minimally processed celery during refrigerated storage. Food Chem., 2006, 94, 68-74.

60. Vinson J.A., Hao Y., Su X., Zubik L., Phenol antioxidant quantity and quality in foods: vegetables. J. Agric. Food Chem., 1998, 46, 3630-3634.

61. Wang H., Cao G., Prior R.L., Oxygen radical absorbing capacity of anthocyanins. J. Agric. Food Chem., 1997, 45, 304-309.

62. Wieczorek C., Traczyk I., The effect of storage and some technological processes for nitrate, nitrite and vitamin $\mathrm{C}$ content in white cabbage. Żyw. Człow. Metab. 1995, 22(2), 165-173 (in Polish).

63. Wu X., Beecher G.R., Holden J.M., Haytowitz D.B., Gebhardt S.E., Prior R.L., Lipophilic and hydrophilic antioxidant capacities of common foods in the U.S. J. Agric. Food Chem., 2004, $52,4026-4037$.

Submitted: 26 September 2015. Revised: 18 January 2016. Accepted: 20 April 2016. Published on-line: 5 September 2016. 